freedom is the Other as object of ethical responsibility and moral concern" (s.242). Det ansvar, man som forbruger udviser, gælder ikke den Anden, men kun en selv. Således synes Bauman at mene, at Løgstrups menneskesyn - at vi i udgangspunktet altid møder den Anden med tillid - er en smule naivt, når man ser på verden $i$ dag, hvor det helt modsatte menneskesyn er dominerende: "strangers are not to be trusted" (s.245). De andre er ikke medmennesker, men først og fremmest konkurrenter: "In a game of survival, trust, compassion and mercy (the paramount attributes of Løgstrup's 'sovereign expressions of life') are suicidal' (s.246).

I det globale samfund gælder, at det enkelte menneskes handlinger ikke længere er begrænset $\mathrm{i}$ tid og rum, hvorfor de kan have uoverskuelige konsekvenser: "What we do (or abstain from doing) may influence the conditions of life (or death) of people in places we will never visit and of generation we will never know" (s.255). Globaliseringen har derfor nok skabt en større global interdependens, men desværre ikke en tilsvarende større global solidaritet. De globale udfordringer kræver globale svar, hvilket ifølge Bauman ikke kan findes i Lévinas' og Løgstrups etik. Bauman er således ikke enig med Ole Jensen $i$, at der i Løgstrups etik skulle være potentiale for en global etik.

Uanset om man er kender af Den etiske fordring eller endnu har til gode at læse den, vil Livtag med den etiske fordring være berigende for den læser, der er interesseret i etik, teologi, politik, litteratur - og alt, hvad der ligger derimellem. Herfra skal således lyde en klar opfordring til at give sig i kast med begge bøger.

Maria Lonise Odgaard Moller

\section{Arkitekturens sociale dimension}

Niels Bjorn (red.): Arkitektur der Forandrer - fra ghetto til velfungerende byomrade, Gads Forlag 2008, 24 sider, 299 kr.

Arkitektur er ikke bare neutrale containere for menneskenes liv og samliv. Arkitektur kan være meningsgivende rammer, der kan skærme, definere funktioner og understøtte individernes erfaring af egne handlemuligheder og sociale sammenhænge. Værket Arkitektur der Forandrer - fra Ghetto til velfungerende byområde har som erklæret mål at vise at sociale problemer i udsatte byområder områder kan afhjælpes gennem inddragelse af arkitektoniske løsninger i forandringsstrategierne. Bogen forsøger såvel at give researchbaserede bud på, hvad der er galt i de danske udsatte byområder, som at anvise alternative løsningsforslag hvor sociale og arkitektoniske indgreb kan understøtte hinanden.

Bogen rummer beskrivelser af de sidste 150-års byudvikling, afrapporteringer for forskellige workshops afholdt i belastede byområder i Danmark og ikke mindst, og her er en af bogens største fortjenester, inspirerende beretninger fra udenlandske løsningsmodeller. En række artikler 
giver således eksempler på, hvordan man i lande som Frankrig, Spanien, Holland, Storbrittanien og USA har ladet forskellige fysiske indgreb og radikale opgør med den modernistiske boligblok-arkitektur bidrage til at giver kvarterer sociale løft og nyt liv og identitet.

Den af den scheizisk-franske arkitekt Le Corbusier inspirerede modernistiske funktionsopdelte bytype har vist sig at have en række indbyggede potentielle svagheder. Le Corbusier drømte i 1930'erne om at skabe sunde, funktionelle, gode og demokratiske boliger til folket. Men den omsætning af hans ideer, der blev sat i værk i 1960'erne og 1970'erne, muliggjort af udviklingen $i$ industrien og byggefaget, har resulteret i massevis af ens udseende boligkarreer på store kønsløse græsarealer. Men, surprise, også de fattige - der er endt med at bebo disse områder - vil gerne kunne påvirke og efterlade mærker i deres egen bolig og dermed bebo den i dybere forstand.

Man arbejder $i$ disse år med en række strategier til at omdanne modernistiske boligområder til nye byog bygningstyper. Et af problemerne med den klassiske modernistiske højhusklynge er, at de fælles arealer er anonyme og ikke henvender sig til specifikke målgrupper eller aktiviteter, og således heller ikke i særlig stor grad opfordrer til socialt samvær eller personlige tilegnelser af rummene. Monotone udformninger af bygninger giver ydermere ringere orienterings- muligheder hvilket ofte vil indvirke negativt på oplevelsen af at opholde sig i rummene.

Flere af bogens bidrag hævder, at de fysiske tiltag i de danske Ghettoområder har haft alt for meget karakter af overfladisk fernis i stedet for dyberegående ændringsforslag. Bogen introducerer en række forskellige løsningsforslag og strategier og viser, hvorledes man flere steder i udlandet med succes er gået langt mere radikalt til værks. Man har eksempelvis i Vaulx-en-Velins i Lyon i Frankrig nedrevet bygninger for at bygge tætlavt frem for i højden, anlagt parker, haver og legepladser og skabt mere åbne forbindelser til og cirkulation mellem bebyggelsen og den omgivende verden. I boligområdet Bijlmermeer i Amsterdam i Holland har man også taget bulldozerne $\mathrm{i}$ ed og nedrevet over $1 / 4$ af bygningerne. Ud over at ændre infrastruktur, organisering og plan for området har man ændret og differentieret bygningerne fysiske udtryk ved, at de nye bygninger er tegnet af forskellige arkitekter og fremstillet i forskellige materialer. Fælles for denne type tiltag er, at man giver de offentlige arealer flere funktioner, identitetsmarkører og udtryk.

Urban fortætning er en anden dermed forbundet strategi, man i øjeblikket arbejder med mange steder for at styrke områders identitet, aktiviteter, liv, diversitet og omdømme. I den igangværende ombygning af $\mathrm{K} \varnothing$ benhavns havn har man til eksempel set en udvikling fra i den første fase 
primært at skabe monofunktionelt kontor- og boligbyggeri til forsøg på at skabe områder med en multifunktionel blanding af butikker, erhverv, kultur og boliger. Inden for saneringen af udsatte byrområder har urban fortætning ligeledes vist sig at være en frugtbar strategi.

Maria Bak Mortensen og Niels Bjørns bidrag Ikonmageri og Imageforandring omhandler den såkaldte ikonstrategi. I Holland og Madrid har man ladet statsejede og kommunale boligselskaber entrere med og lave arkitektkonkurrencer for unge arkitekter, hvilket i flere tilfælde har resulteret i eksperimenterende, opsigtsvækkende og sansestimulerende arkitektur. Ghettobao-effekt kunne man fristes til kalde denne strategi, hvor håbet er, at arkitektkonkurrencerne skaber bedre, smukkere og mere velfungerende bygninger og udearealer med deraf følgende positivt image. Med over 140 konkurrencer for enkeltbyggerier af socialt boligbyggeri er Madrid blevet en legeplads for arkitekter og en række internationalt anerkendte arkitektfirmaer som MVRDV, Foreign Office Architects (F.O.A.) og Morphosis har skabt socialt boligbyggeri i Madrid. (Bjørn og Bak Mortensen 2008: 1157)

Man vil derfor nu kunne gå en tur i Madrid og finde en bambusbeklædt boligblok, med en fremtoning som en forstørret junglehytte og med indbyggede skodder beboerne kan åbne og lukke således at bygningen markant skifter udseende. En bygning der ta- ler til flere sanser også den taktile. Der er ikke kun i Madrid at socialt boligbyggeri nu inviterer til nærkontakt af første grad. Éduard François har i det 17.arrondisement i Paris i bogstaveligste forstand ladet en social boligblok med navnet Tower Flower blomstre op. Med 380 store tilplantede potter indstøbt i ydermurene han man skabt en vertikal have, en levende, duftende og fuglefløjtende facade og et unikt bosted.

Hvor ikonstrategien ofte bygger til et forestillet fremtidigt klientel, så har man også set succesfulde tiltag der inddrager og tager udgangspunkt $i$ de eksisterende beboeres drømme, værdier og hverdagserfaringer. Flere kapitler i bogen som eksempelvis Marie Bak Mortensens Lighedstanken i ny udgave peger i den forbindelse på bevægelsen New Urbanism der har præget den amerikanske modernismekritik. Hos New Urbanism hentes blandt andet inspiration til ønsket om at styrke beboeres ejerskabs og ansvarsfølelse og integrere de enkelte kvarterer i de omgivende bydele. Et andet problem med udsatte boligområder er nemlig, at de ofte fremstår som isolerede øer, der adskiller sig fra det omgivende samfund. Forbedring af beboernes ejerskabs- og ansvarsfølelse kan blandt andet ske ved at anlægge små privathaver og nyttehaver i tilknytning til husene. I Rotterdam har man indført en model man kalder "Do it yourself", hvor kommunen vælger nogle af de boligblokke der er i ringest forfatning $\mathrm{i}$ belastede boligområder 
og enten forærer dem væk eller sælger dem til spotpris til borgere, der vil gå sammen i en boligforening og selv betale for og arrangere renoveringen.

Som det fremgår af flere af bidragene er Danmark et af de lande, hvor man har været mest tøvende med at svinge nedrivningskuglen, og der er da heller ikke altid at nedrivning er den bedste løsning hverken socialt, økonomisk eller miljømæssigt. Flere bidrag diskuterer fordele og ulemper ved nedrivning og peger alternativt på diverse transformationsstrategier, der forsøger at tage udgangspunkt $i$ de arkitektoniske kvaliteter og potentialer der er i områderne og bygge videre på dem.

Bogen har selvsagt et politisk sigte i ønsket om at mindske social og etnisk segregering, men $i$ sin form og formuleringer er den præget af, at den henvender sig til en bred målgruppe, og det kan der i dette tilfælde være god mening i. Såvel politikere, embedsmænd, arkitekter som andre offentlige eller private forvaltere og brugere af byrum vil med fordel kunne hente inspiration og forståelse. Selv om økonomiske og sociale problemer selv sagt ikke kan løses alene ved fysiske transformationer, så bidrager det fysiske rum afgørende til det sociale liv der leves i byerne. Arkitektur udgør rammerne for vores fælles liv med hinanden. Bygninger og rum kan både praktisk og mentalt fungere som eksternaliseringer og tydeliggørelser af menneskets forestillinger, emotioner og visioner og bidrage til at ramme- sætte og artikulere såvel vores individuelle erfaringer som vores kollektive møder og samvær.

De fysiske omgivelser kan befordre, forhindre og strukturere bestemte handlinger. Men påvirkningen er gensidig. Der er et rigt felt for gensidig udveksling mellem kroppen og de konstruerede fysiske omgivelser. Der pågår i rummet en vedvarende dialog mellem lokalernes funktion, interiør og indretning og brugerens praksis og intentioner. De er tætte relationer mellem sociale, rumlige og mentale strukturer. Menneskene og deres handlinger formgiver og efterlader spor $i$ omgivelserne, der skaber betydninger, muligheder og begrænsninger. Værket Arkitektur der forandrer er indirekte også et forsvar for en arkitektur der i højere grad inddrager kroppen og det hele menneske.

Selvom bogen ikke foretager nogle egentlige arkitekturteoretiske landvindinger $o g$ en og anden ganske givet vil savne en mere kritisk omgang med ghetto-begrebet og de problemstillinger omkring social segregering der er forbundet med ghetto-diskursen, så skal bogen alt i alt hilses varmt velkommen. I disse år hvor det offentlige rum fra forskellig side er under transformation og pres er Arkitektur der forvandler et værdifuldt bidrag såvel i debatten omkring som ikke mindst forhåbentlig i den faktiske fremtidige forvaltning af de udsatte byområder.

Lonise Fabian 